\title{
PROGRESS VERSUS PRODUCTION COSTS OF LIVE BROILER CHICKENS IN POLAND BETWEEN 1994 AND 2015
}

\begin{abstract}
The paper presents analysis of influence of total agriculture progress on changes of unit costs in broiler chicken production in 1994-2015. Results of annual assessment of utility value of broiler chicken in Poland were taken as a measure of total progress in production. This assessment was carried out by Central Animal Breeding Office (1994-2000), National Centre of Animal Breeding (2001-2003), and National Poultry Council (2004-2015). All analysed indices improved between 1994 and 2015 as followes: feed conversion ratio from 2.52 to $1.66 \mathrm{~kg} / \mathrm{kg}$, daily mass increment from 38.1 to $60.0 \mathrm{~g} /$ day, mortality from $9 \%$ to $4.3 \%$. In 1994-2015, unit costs of broiler production (expressed in constant prices of 1994) decreased by $36 \%$. Up to 2003 , decrease in costs was on average $2.5 \%$ yearly and since 2004 the decrease was on average 1\% yearly. The strongest influence on lowering broiler chickens production costs (22\%) was exerted by the decrease in feed costs due to improvement of feed conversion ratio, decrease in other costs (9\%) and the purchase amount of material for breeding and costs of purchase of one-day chicks (5\%).
\end{abstract}

Keywords: agricultural progress, broiler chickens, feed conversion ratio, mortality, daily increment of mass, unit production costs.

JEL codes: D24, Q11, Q12, Q13.

\section{Introduction}

Progress in agriculture is defined as qualitative and quantitative changes which in economic sense mean reduction of social inputs per unit of a food product (Woś, 1996). The following types of progress in agriculture can be 
distinguished: biological, technical, organisational, technological and socio-economic (Klepacki, 1990; Wawrzyniak, 2003). Biological progress translates into improvement in genetic properties of plants and animals, making them more productive in terms of using the forces of nature and industrial means of production, and increasing their quality from the point of view of consumer requirements. This type of progress is possible thanks to specific substitution of physical inputs and it leads to reduced costs of agricultural production $(\mathrm{Ru}-$ nowski, 1997; Wicki, 2010). Individual types of progress are often interdependent. Commonly used animal production indicators, such as daily mass increment or feed conversion ratio, characterise biological progress as an effect of genetic improvement of breeds or hybrids in terms of mass increment or feed conversion rate. Particularly good results are obtained by striving at simultaneous biological, technical, technological and organisational progress. The effects of genetic progress are visible only when appropriate, strictly defined breeding conditions are ensured, along with appropriate quality feed and veterinary services. It is difficult to fully benefit from biological progress if obsolete production techniques or technologies are used (Runowski, 2009). Progress is a relative term and does not exist as such. It is only present when we compare current achievements with the past situation.

Core determinant in producers' decisions making is to achieve an adequate agricultural income, understood as the difference between the value of commercial production and the incurred production costs (Banaś, 2004; Żmija, 1999).

In 2005-2014, the European Union countries recorded an upward trend in agricultural income per full-time worker (Runowski, 2015). Poland was among the leaders in terms of income growth rate, but in absolute values per full-time agricultural worker it was ranked only 23rd. Particularly strong growth in poultry production was recorded after Poland's accession to the European Union, and it resulted from an increasing domestic and foreign demand (Dybowski, 2014; Stańko, 2011; Żmija and Czekaj, 2013). Favourable poultry prices were due to low production costs, compared to those in Western European countries (Czyżewski and Danilczuk, 2008). Currently, Poland is the EU leader in poultry production, which amounted to 2,386 thousand tonnes in 2015 (Rynek Drobiu i Jaj, 2016).

The aim of the article is to assess changes in main technological indicators and unit cost between 1994 and 2015, which took place due to progress in broiler chicken production.

\section{Material and methods}

The analysed material encompassed two groups of data. The first one comprised results of assessments of broiler chickens utility value, performed in Warsaw (2004-2015) by Central Animal Breeding Station (1994-2000), National Centre of Animal Breeding (2001-2003), and National Poultry Council - 
Chamber of Commerce. The data came from broiler chicken farms from all over Poland. The analysis covered the following production outcomes in individual years: feed conversion ratio per $1 \mathrm{~kg}$ of body weight, daily mass increment, average final mass, duration of the production cycle, and mortality. The indicators were calculated based on a large sample, since the analysis covered 720 herds a year on average, from 337 herds in 1995 to 1176 in 2015. The measure of progress between 1994 and 2015 was changes in production indicators.

The second group of data comprised prices of live broilers, chicks and feed. The data were taken from the biannual publication entitled Rynek Drobiu i Jaj (Poultry and Egg Market), published in 1994-2004 as well as from the database of the Integrated Agricultural Market Information System (2004-2015).

Progress allows to reduce inputs for obtaining the same production volume, and thus to cut unit costs. Unit costs of live broiler production $(\mathrm{Kj})$ were calculated using the following formula (Kucka, 1999):

$$
K_{j}=W \cdot C+N_{p} \cdot C_{p}+T_{p} \cdot Z
$$

where:

$W$ - feed conversion ratio $(\mathrm{kg} / \mathrm{kg})$,

$C$ - average price of feed (PLN/ $\mathrm{kg}$ ),

$N_{p}$ - input of day-old chicks (chick $/ \mathrm{kg}$ ),

$C_{p}$ - price of chicks (PLN/chick),

$T_{p}-$ duration of production (day $/ \mathrm{kg}$ ),

$Z$ - unit value of other costs (PLN/kg per day).

Unit production costs of live chicken mass comprise three elements: (1) cost of feed, (2) cost of purchase of day-old chicks, and (3) other costs. The impact of a given component on costs is defined by its unit price multiplied by its input required to produce one kilogram of live chicken. The quantity of feed required to produce $1 \mathrm{~kg}$ of live chicken is directly defined by the feed conversion ratio, expressed in $\mathrm{kg} / \mathrm{kg}$ and denoting how many kilograms of feed was used to produce $1 \mathrm{~kg}$ of live chicken. The input of day-old chicks was calculated according to the following formula:

$$
N_{p}=(1+U \cdot 0,01) / M_{k}
$$

where:

$U$ - mortality rate (\%),

$M_{k}$ - average final weight ( $\mathrm{kg} /$ number $)$.

Time required to produce one $\mathrm{kg}$ of live chicken was calculated according to the following formula: 


$$
C_{p}=M_{k} /\left(P_{d} \cdot 0,001\right)
$$

where:

$P_{d}$-average daily mass increment (g/day).

Other costs included the costs of power, fuel, amortisation, labour and other costs related to the functioning of a farm as well as fixed annual fees. The amount of these costs in relation to a time unit is relatively constant (Kucka, 1999).

The European broiler index (EBI) was calculated according to the following formula (Świerczewska, Stępińska and Niemiec, 1999):

$$
E W W=\left[\left(M k \cdot P_{\%}\right) /(D \cdot W)\right] \cdot 100
$$

where:

$E B I$ - European broiler index (points),

$P_{\%}$ - average survival rate in the entire population of chickens for fattening (\%), $D$ - duration of fattening (days).

Other indications as in formula 1 and 2.

Calculations and analyses were performed using constant prices from 1994 and actual values of individual production factors in individual years (Wyniki oceny 1995-2016). In order to eliminate the impact of inflation, nominal prices were converted into constant prices from 1994 (prices from $1994=100 \%$ ).

\section{Results}

The average live broiler price in 1994 was $2.29 \mathrm{PLN} / \mathrm{kg}$. Within 22 years covered by the analysis, nominal prices of live broilers increased by $52 \%$ (Fig. 1) to $3.48 \mathrm{PLN} / \mathrm{kg}$ in 2015 . Nominal prices grew mainly in the first three years under analysis (by 40\%), as a result of high inflation at that time, and in 2007-2013 due to a higher demand resulting primarily from an increase in export. Between 1998 and 2013, nominal prices declined by $33 \%$.

Real prices of live broilers were subject to cyclical fluctuations, and fell by $30 \%$ in 1994-2015. Two trends were observed: first prices dropped by $40 \%$, and starting from 2004, a reverse trend was recorded - after stabilisation, prices began to slowly increase, by $10 \%$ in 2004-2015. A deep but short price drop in 2006 was related to the avian influenza outbreak.

Feed and chicks were the means of production accounting for most of the production costs (approximately 80\%). Nominal prices of feed in 1994-2005 were subject to cyclical fluctuations and increased by $162 \%$ in the said period, while real prices increased by $34 \%$ (Fig. 2). Prices of chicks were more stable. In the analysed period, nominal prices of chicks grew by $63 \%$, while their real prices fell by $17 \%$. 


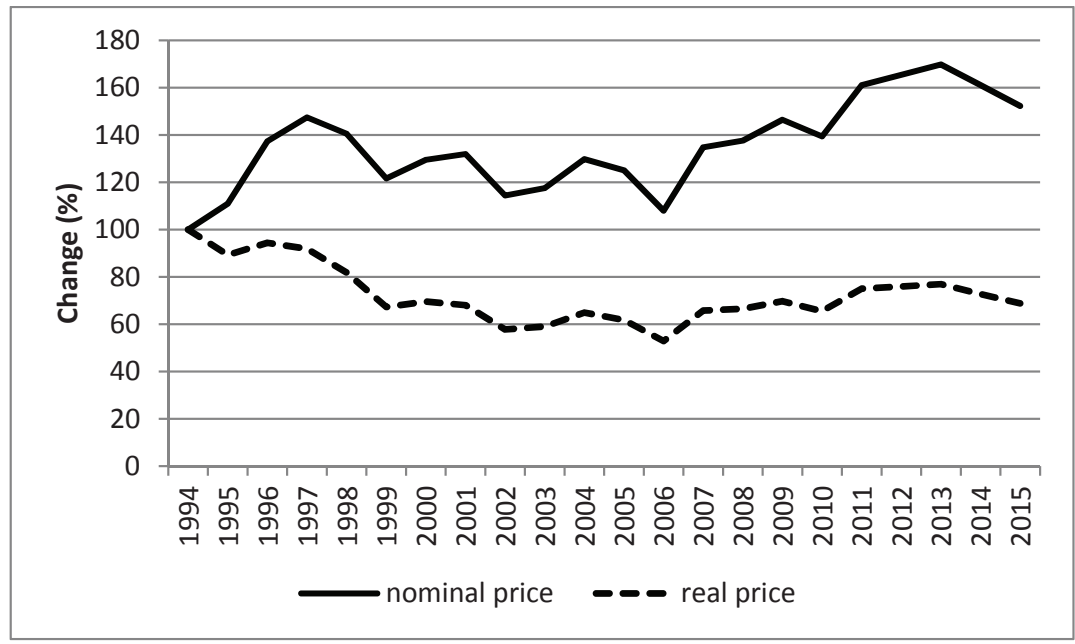

Fig. 1. Changes in nominal and real prices of live broiler chickens in Poland between 1994 and 2005 (baseline year $1994=100 \%$ ).

Source: own calculations based on biannual publication Rynek Drobiu i Jaj for 1994-2016 and from the database of the Integrated Agricultural Market Information System in 2016.

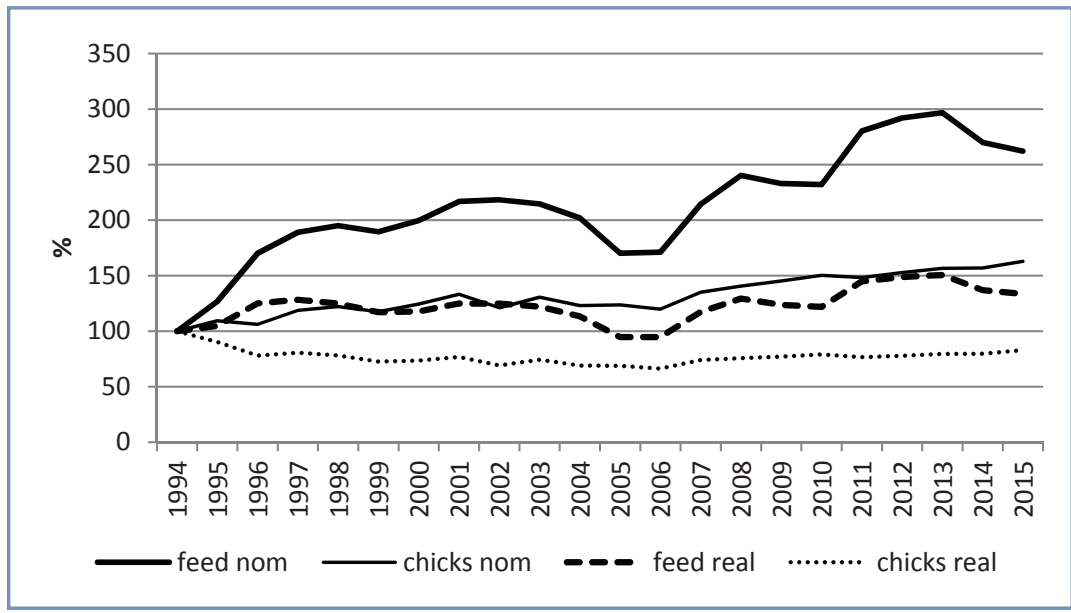

Fig. 2. Changes in nominal (nom.) and real (real.) prices of feed and chicks between 1994 and 2005 (baseline year $1994=100 \%$ ).

Source: as for Fig. 1.

Profitability of production is largely determined by the relation of product prices to input, informing how many units of input for one product unit may be purchased. 
In $1994,4.5 \mathrm{~kg}$ of feed could be purchased for $1 \mathrm{~kg}$ of sold live broiler chicken.

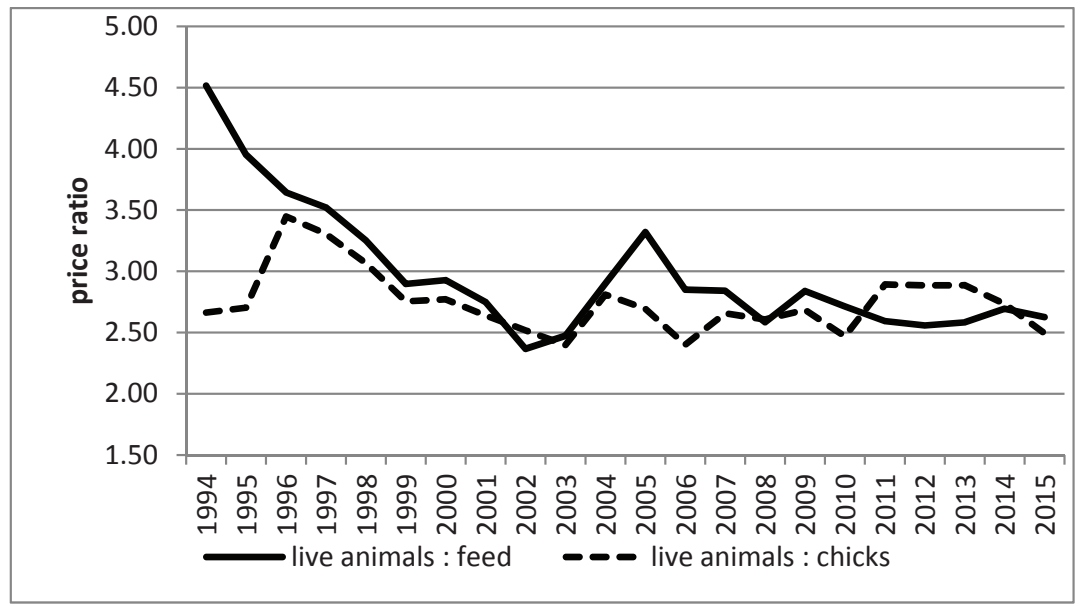

Fig. 3. Ratio of prices of live broiler chickens to prices of feed and day-old chicks between 1994 and 2015.

Source: as for Fig. 1.

In the following years, the ratio deteriorated regularly, falling to its lowest level $(2.37: 1)$ in 2002. Since 2006, the ratio of prices of live broiler chickens to prices of feed stabilised and fluctuated between 2.56 and 2.85. Olszańska (2012), analysing the ratio of buying-in prices of animal products in these years, has noticed that statistically less feed is used to produce $1 \mathrm{~kg}$ of live animals, and thus in subsequent years lower ratios of prices of live animals to prices of main feeds are acceptable.

The ratio of prices of live chickens to prices of chicks in 1994-1995 equalled 2.70:1 and was significantly lower than the ratio of prices of live chickens to prices of feed. From 1996, the live chickens to chicks price ratio was similar to the ratio of live chickens to feed prices, and it followed similar trends.

Technological indicators of live broiler chicken production in 1994-2015 improved significantly (Fig. 4). The feed conversion rate amounted to $2.52 \mathrm{~kg} / \mathrm{kg}$ on average in 1994, and the long-term linear trend $(\mathrm{a}=-0.031, \mathrm{R} 2=0.847)$ reveals that the indicator decreased by $0.03 \mathrm{~kg} / \mathrm{kg}$ on average a year - to $1.66 \mathrm{~kg} / \mathrm{kg}$ in 2015. Daily mass increment was $38.1 \mathrm{~g} /$ day in 1994 and grew by $1.05 \mathrm{~g}$ a year on average, reaching $60.0 \mathrm{~g} /$ day in 2015 . The mortality rate (during the entire production cycle) was $9.0 \%$ in 1994 and it decreased by $0.21 \%$ annually, totalling $4.3 \%$ in 2015 . The European broiler index amounted to 131.9 points in 1994 and grew by 8.9 points annually, reaching 345.9 points in 2013 . 


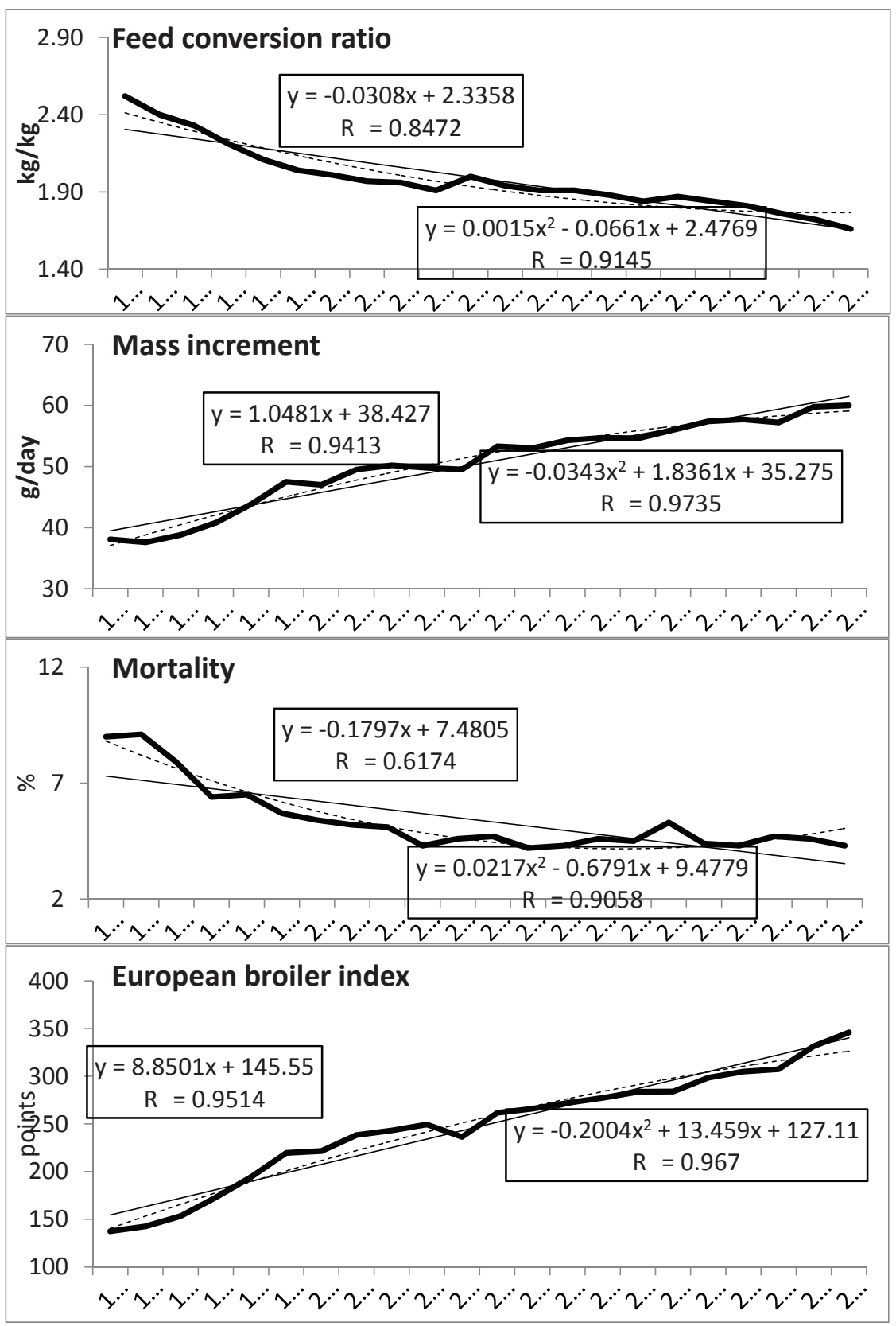

Note: The thin line presents the trend: solid line - linear trend; dashed line - quadratic function.

Fig. 4. Technological indicators of live broiler chicken production in Poland in 1994-2015. Source: Results of the assessment of utility value of poultry, 1995-2016. 
Production indicators did not improve at the same rate throughout the entire period. The long-term trend described by a quadratic function for all indicators is much better aligned with empirical data (R2 indicators amount from 0.915 for feed conversion ratio to 0.974 for mass increment). An analysis of the trend quadratic function shows that improvement of production indicators in the first half of the analysed period (1994-2003) was much more pronounced than in the second half (2004-2015).

The unit cost of live broiler chicken production in 1994 amounted to 2.09 PLN/ $\mathrm{kg}$, of which the cost of feed represented 1.29 PLN $/ \mathrm{kg}(62 \%)$, the cost of chicks $0.47 \mathrm{PLN} / \mathrm{kg}$ (22\%), and other costs - $0.33 \mathrm{PLN} / \mathrm{kg}$ (26\%) (Table 1).

Table 1

Production means input and unit costs of live broiler chicken production in Poland in the years 1994-2014, in constant prices from 1994

\begin{tabular}{|c|c|c|c|c|c|c|c|c|c|}
\hline \multirow{2}{*}{ Year } & \multicolumn{2}{|c|}{ Feed input } & \multicolumn{2}{|c|}{ Chicks input } & \multirow{2}{*}{$\begin{array}{c}\text { Final } \\
\text { mass kg/ } \\
\text { chick }\end{array}$} & \multirow{2}{*}{$\begin{array}{c}\text { Production } \\
\text { time } \\
\text { day } / \mathrm{kg}\end{array}$} & \multicolumn{2}{|c|}{ Other costs } & \multirow{2}{*}{$\begin{array}{l}\text {-Total costs } \\
\text { PLN/kg }\end{array}$} \\
\hline & $(\mathrm{kg} / \mathrm{kg})$ & $\mathrm{PLN} / \mathrm{kg}$ & chick./kg & PLN/kg & & & $\begin{array}{c}\mathrm{PLN} / \mathrm{kg} \\
\text { daily }^{\mathrm{a}}\end{array}$ & PLN/kg & \\
\hline 1994 & 2.52 & 1.29 & 0.55 & 0.47 & 1.98 & 26.26 & 0.013 & 0.33 & 2.09 \\
\hline 1995 & 2.40 & 1.22 & 0.57 & 0.49 & 1.92 & 26.56 & 0.013 & 0.33 & 2.04 \\
\hline 1996 & 2.33 & 1.19 & 0.56 & 0.48 & 1.94 & 25.77 & 0.012 & 0.31 & 1.98 \\
\hline 1997 & 2.21 & 1.13 & 0.54 & 0.47 & 1.96 & 24.49 & 0.012 & 0.29 & 1.89 \\
\hline 1998 & 2.11 & 1.08 & 0.52 & 0.44 & 2.06 & 22.82 & 0.010 & 0.23 & 1.75 \\
\hline 1999 & 2.04 & 1.04 & 0.51 & 0.43 & 2.09 & 21.05 & 0.010 & 0.20 & 1.67 \\
\hline 2000 & 2.01 & 1.03 & 0.51 & 0.44 & 2.07 & 21.26 & 0.009 & 0.20 & 1.67 \\
\hline 2001 & 1.97 & 1.00 & 0.49 & 0.42 & 2.13 & 20.19 & 0.009 & 0.19 & 1.61 \\
\hline 2002 & 1.96 & 1.00 & 0.48 & 0.41 & 2.21 & 19.91 & 0.008 & 0.16 & 1.57 \\
\hline 2003 & 1.91 & 0.97 & 0.49 & 0.42 & 2.14 & 20.09 & 0.008 & 0.16 & 1.55 \\
\hline 2004 & 2.00 & 1.02 & 0.48 & 0.41 & 2.18 & 20.18 & 0.008 & 0.17 & 1.60 \\
\hline 2005 & 1.94 & 0.99 & 0.46 & 0.39 & 2.29 & 18.78 & 0.008 & 0.15 & 1.53 \\
\hline 2006 & 1.91 & 0.97 & 0.46 & 0.39 & 2.28 & 18.86 & 0.008 & 0.15 & 1.51 \\
\hline 2007 & 1.91 & 0.97 & 0.46 & 0.39 & 2.28 & 18.42 & 0.009 & 0.16 & 1.52 \\
\hline 2008 & 1.88 & 0.96 & 0.45 & 0.38 & 2.35 & 18.30 & 0.009 & 0.16 & 1.50 \\
\hline 2009 & 1.84 & 0.94 & 0.47 & 0.40 & 2.24 & 18.30 & 0.008 & 0.15 & 1.49 \\
\hline 2010 & 1.87 & 0.95 & 0.44 & 0.38 & 2.41 & 17.84 & 0.009 & 0.16 & 1.49 \\
\hline 2011 & 1.84 & 0.94 & 0.42 & 0.36 & 2.47 & 17.41 & 0.009 & 0.15 & 1.45 \\
\hline 2012 & 1.81 & 0.92 & 0.42 & 0.36 & 2.48 & 17.34 & 0.008 & 0.15 & 1.43 \\
\hline 2013 & 1.76 & 0.90 & 0.43 & 0.37 & 2.44 & 17.62 & 0.009 & 0.15 & 1.42 \\
\hline 2014 & 1.72 & 0.88 & 0.43 & 0.37 & 2.45 & 16.73 & 0.009 & 0.15 & 1.40 \\
\hline 2015 & 1.66 & 0.84 & 0.41 & 0.36 & 2.52 & 16.67 & 0.008 & 0.14 & 1.34 \\
\hline
\end{tabular}

${ }^{a}$ Based on Utnik-Banaś (2016).

Source: Results of assessment of utility value of poultry, 1995-2015, and biannual publication Rynek Drobiu i Jaj from 1994-2016. 
In the following years, unit costs were gradually decreasing (in terms of constant prices of production means in 1994) (Fig. 5). In the adopted method of unit cost calculation (formula no 1) and with assumed constant prices, the components of total costs depended directly on the achieved production results. The cost of feed was calculated as feed conversion rate multiplied by unit price of feed. The decrease of feed conversion rate from 2.52 to $1.66 \mathrm{~kg} / \mathrm{kg}$ in $1994-2005$ contributed to a drop in feed costs by $35 \%$ and to a decline of total unit cost of live broiler chicken production by $22 \%$.

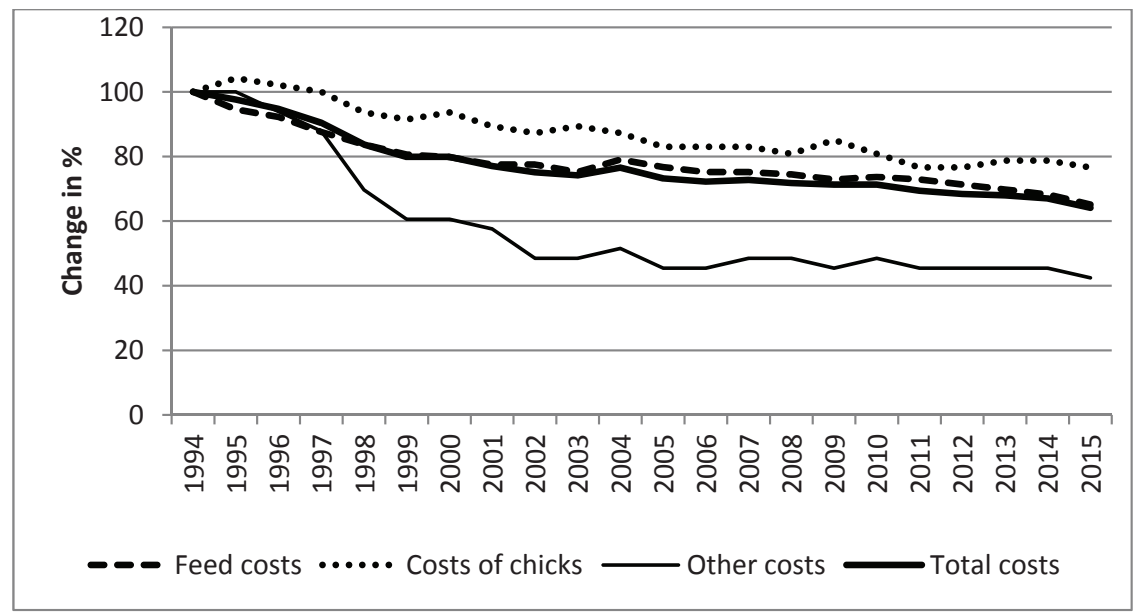

Fig. 5. Changes in unit costs of live chicken production (and their components) in the years 1994-2014 (constant prices from $1994=100 \%$ ).

Source: Results of the assessment of utility value of poultry, 1995-2015, and biannual publication Rynek Drobiu i Jaj from 1994-2016.

The purchase cost of day-old chicks depended on unit input of day-old chicks required to produce $1 \mathrm{~kg}$ of live chicken (formula 2). The input depended directly on two indicators: mortality rate and final body weight. The reduction in mortality by $1 \%$ (with the constant final weight) translated directly into reduction of chicks input by $1 \%$. The increase of the final body weight in the analysed period was in inverse proportion (decrease) to chicks input. The decline in mortality rate from 9\% (1994) to 4.3\% (2015), accompanied by an increase in final body weight from 1.98 to $2.52 \mathrm{~kg} / \mathrm{chicken}$ in the same period, contributed to reduction of chick purchase costs by $23 \%$ and to a $5 \%$ drop in total unit costs.

The level of other costs per time unit is relatively constant and thus the increased rate of daily mass increment caused a reduction of this component of production costs. An increase in daily mass increment from $38.1 \mathrm{~g} /$ day in 1994 to $60.0 \mathrm{~g} /$ day in 2015 translated into shorter production time of $1 \mathrm{~kg}$ of live 
chicken - from 26.3 days (in 1994) to 16.7 days (in 2015). The shorter production time contributed to reduction of other costs by $58 \%$ and to cutting the total cost of live chicken production by $9 \%$. An important factor contributing to reduction of this group of costs was an increase in stock density per $1 \mathrm{~m}^{2}$, which led to a decrease in unit value of other costs from 0.013 to $0.008 \mathrm{PLN} / \mathrm{kg}$ per day. In June 2010, Council Directive 2007/43/EC entered into force. It laid down the limits of acceptable number of birds kept on a unit of useable area, which significantly reduced the room for cutting other fixed costs (Utnik-Banaś, Żmija and Sowula-Skrzyńska, 2014).

Summing up, the unit cost of live broiler chicken production dropped by $36 \%$ between 1994 and 2005, with the decrease not being evenly distributed over the years. In 1994-2003, the costs decreased by $2.5 \%$ a year on average, while between 2004 and 2015 the decrease rate fell by over a half, and amounted to $1 \%$ on average. The trends overlap with the intensity of progress, measured by changes in production indicators which improved much more significantly in the first (low level of indicators at the beginning) than in the second analysed period.

\section{Summary and conclusions}

This paper analyses the impact of agricultural progress on changes in costs of live broiler production in 1994-2015. Progress was measured by changes in the following indicators, characterising live chicken production: daily mass increment, feed conversion rate per $1 \mathrm{~kg}$ of body weight, final broiler weight, mortality and health problems, and duration of production. The indicators were defined based on assessment of the utility value of broilers kept on farms across Poland, which covered 700 of production stock on average per year. Systematic improvement of production indicators points to overall progress in live chicken production in the analysed period, comprising biological, technical, technological, chemical, organisational and economic progress. In practice, it is very difficult to define separately the effects of individual types of progress, since they are interrelated and interdependent.

Unitary production costs were calculated as the sum of products of the input of a given production factor required to produce $1 \mathrm{~kg}$ of live chicken multiplied by the unit price of this factor. Individual inputs were expressed as production indicators, which allowed to use the adopted progress intensity measures to determine the costs. The adoption of constant prices allowed to eliminate the impact of inflation and the price ratios changing within the analysed period.

Overall agricultural progress led to improvement of the analysed production indicators, which translated into higher economic effects.

1. The decrease of feed conversion rate from 2.52 to $1.66 \mathrm{~kg} / \mathrm{kg}$ contributed to a drop in feed costs by $35 \%$ and to decline of total unitary cost of live chicken production by $22 \%$. 
2. The decline in mortality rate from $9 \%$ to $4.3 \%$ and the increase in final body weight from 1.98 to $2.52 \mathrm{~kg} /$ chicken allowed to reduce day-old chick purchase costs by $23 \%$ and to cut unit costs by $5 \%$.

3. The increase in daily mass increment from $38.1 \mathrm{~g} /$ day to $60.0 \mathrm{~g} /$ day allowed to reduce the production time of $1 \mathrm{~kg}$ of live chicken from 26.6 to 16.7 days, to cut other costs by $58 \%$ and the unitary costs of live broiler production by $9 \%$.

4. Real prices of live broilers fell by $30 \%$ between 1994 and 2005. A downward trend prevailed before Poland's accession to the European Union (1994-2003) with real prices of live chickens falling by $40 \%$, while after the accession (2004-2015), real prices slowly increased (by 10\%).

5. Unitary costs of live broiler production in 1994-2005 fell by 36\%. In 1994-2003 , the costs decreased by $2.5 \%$ a year on average, while between 2004 and 2015 the costs fell by $1 \%$ a year on average. 


\section{References}

Banaś, K. (2004). Wpływ poziomu cen na opłacalność produkcji kurcząt brojlerów. Roczniki Naukowe Zootechniki, no. 31(2), pp. 299-307.

Czyżewski, A., Danilczuk, J. (2008). Konkurencyjność polskiego rynku drobiu i jaj w wymianie z Unią Europejską. Roczniki Naukowe SERiA, no. 4(10), pp. 56-61.

Dybowski, G. (2014). Podstawy konkurencyjności polskiej branży drobiarskiej. Studia i Monografie, no. 160. Warsaw: IERiGŻ-PIB.

Klepacki, B. (1990). Organizacyjne i ekonomiczne uwarunkowania postepu technologicznego $w$ gospodarstwach indywidualnych (na przykładzie produkcji roślinnej). Warsaw: Wydawnictwo SGGW-AR.

Kucka, E. (1999). Koszty produkcji drobiu rzeźnego. In: R. Kisiel (ed.), Ekonomika produkcji rolniczej. Olsztyn: Wydawnictwo Akademii Rolniczo-Technicznej.

Olszańska, A. (2012). Rynek żywca w Polsce (1955-2010) - zmiany strukturalne, koncentracja produkcji $i$ wahania podaży. Monografie i Opracowania, no. 214. Wrocław: Wydawnictwo Uniwerytetu Ekonomicznego.

Runowski, H. (1997). Postep biologiczny w rolnictwie. Warsaw: Wydawnictwo SGGW.

Runowski, H. (2009). Tendencje zmian w organizacji i ekonomice przedsiębiorstw rolnych - aspekty teoretyczne. Zeszyty Naukowe SGGW, Ekonomika i Organizacja Gospodarki Żywnościowej, no. 75, pp. 197-210.

Runowski,H.(2015). Kierunki i skala zmian dochodów rolniczych w krajach Unii Europejskiej w latach 2005-2014. Roczniki Naukowe SERiA, vol. XVII, book 6, pp. 233-239.

Rynek Drobiu i Jaj. Analizy Rynkowe (1994-2016). Warsaw: IERiGŻ, ARR, MRRiW.

Stańko, S. (2011). Tendencje w produkcji, konsumpcji i handlu mięsem drobiowym w Polsce w latach 1990-2009. Zeszyty Naukowe SGGW, Problemy Rolnictwa Światowego, no. 11(26), pp. 161-168.

Świerczewska, E., Stępińska, M., Niemiec, J. (1999). Chów kur. Warsaw: Fundacja Rozwój SGGW.

Utnik-Banaś, K., Żmija, J., Sowula-Skrzyńska, E. (2014). Economic aspects of stocking density reduction in broiler chicken breeding on the example of farms in Southern Poland. Annals of Animal Science, no. 3(14), pp. 663-671.

Utnik-Banaś, K. (2016). Zastosowanie funkcji produkcji Cobba-Douglasa do analizy zmian nakładów w produkcji żywca brojlerów. Roczniki Naukowe Ekonomii Rolnictwa i Rozwoju Obszarów Wiejskich, vol. 103, book 3, pp. 117-126.

Wawrzyniak, B.M. (2003). Doradztwo i postep w rolnictwie polskim. Włocławek: Włocławskie Towarzystwo Naukowe.

Wicki, L. (2010). Efekty upowszechniania postępu biologicznego w produkcji roślinnej. Rozprawy Naukowe i Monografie. Warsaw: Wydawnictwo SGGW.

Woś, A. (1996). Strategiczne problemy rozwoju polskiego rolnictwa. Synteza. No. 21, Warsaw: IERiGŻ.

Wyniki oceny wartości użytkowej drobiu. 1995-2000. Centralna Stacja Hodowli Zwierząt, Warsaw.

Wyniki oceny wartości użytkowej drobiu 2007-2016. National Poultry Council - Chamber of Commerce in Warsaw. 
Integrated Agricultural Market Information System. 2016. Retrieved from: http://www.minrol. gov.pl/pol/ Rynki-rolne (access date: 30 August 2016).

Żmija, J. (1999). Przedsiębiorczość w agrobiznesie a rozwój obszarów wiejskich w Regionie Małopolski. Kraków: Wydawnictwo Czuwajmy.

Żmija, J., Czekaj, M. (2013). Livestock Production in Poland in the Face of Challenges Posed by the Common Agricultural Policy Introduction. Tavrijs'kij Visnik Agrarnoji Nauki, no. 2, pp. 59-65. 
KATARZYNA UTNIK-BANAŚ

Uniwersytet Rolniczy

Kraków

\title{
POSTĘP A KOSZTY PRODUKCJI ŻYWCA BROJLERÓW KURZYCH W POLSCE W LATACH 1994-2015
}

\begin{abstract}
Abstrakt
W pracy badano wpływ ogólnego postepu rolniczego na zmianę kosztów jednostkowych produkcji żywca brojlerów w latach 1994-2015. Za mierniki postepu przyjęto coroczne wyniki oceny wartości użytkowej kurczat brojlerów w Polsce, prowadzonej przez Centralna Stację Hodowli Zwierzat (1994-2000), Krajowe Centrum Hodowli Zwierzat (2001-2003) oraz Krajowa Rade Drobiarstwa (2004-2015). Wszystkie analizowane wskaźniki w okresie 1994-2015 uległy istotnej poprawie: wskaźnik zużycia paszy z poziomu 2,52 do 1,66 kg/kg, przyrost masy odpowiednio z 38,1 do 60,0 g/dobe, natomiast wielkość upadków zmalała z 9 do 4,3\%. Jednostkowe koszty produkcji żywca, wyrażone w cenach stałych z 1994 roku, zmniejszyły sięw latach 1995-2015 o 36\%, przy czym do 2003 roku spadek kosztów nastepowat w tempie 2,5\% rocznie, natomiast od 2004 roku zmniejszenie kosztów zachodziło $w$ średnim tempie $1 \%$ rocznie. Największy wpływ na obniżenie kosztów produkcji żywca brojlerów (o 22\%) miat spadek kosztów pasz spowodowany poprawa wskaźnika konwersji paszy, obniżeniem (o 9\%) kosztów pozostałych i kwoty zakupu materiału do chowu oraz kosztów zakupu piskląt jednodniowych (5\%).
\end{abstract}

Słowa kluczowe: postęp rolniczy, brojlery, wskaźnik zużycia paszy, upadki, przyrost masy ciała, jednostkowe koszty produkcji.

Accepted for print: 16.10.2017.

Unless stated otherwise all the materials on the website are available under the Creative Commons Attribution 3.0 Poland license. Some rights reserved to the Institute of Agricultural and Food Economics - National Research Institute.

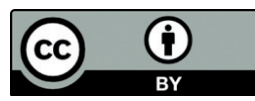

